\title{
DEFINITIONS AND PRACTICES OF RELIGIOUS MINORITIES IN THEIR RELATIONSHIP WITH THE PORTUGUESE STATE: WAYS OF INSTRUMENTALIZATION BY THE MAJORITY
}

\author{
DEFINIÇÕES E PRÁTICAS DE MINORIAS RELIGIOSAS EM SUA RELAÇÃO COM O \\ ESTADO PORTUGUÊS: MEIOS DE INSTRUMENTALIZAÇÃO PELA MAIORIA
}

Paulo Mendes Pinto ${ }^{1}$

\begin{abstract}
Over the last quarter of the 20th century, the newborn democratic regime of Portugal sought not to antagonize the Catholic hierarchy. Aware of the clerical weakened position (after the April Revolution in 1974), the left-wing political forces that gained power after 1974, subtracted little from the church's institutions's public domain.Far from withdrawing those acquired rights, it was given a place to a system where minorities were given the opportunity to rise to the same level of respect that the state granted to the dominant religion. For example, through airtime on radio and public television and confessional space of schools. Because of the value and the respect that are gained, minorities adhered and still adhere to these models defending it as the most perfect realization - as the redaction of the Religious Freedom Act of 2001 reflects perfectly. Today, we have minorities supporting the status quo, defending the place and position of the Catholic church for fear of losing their rights by, in practice, decreasing the power of the majority.
\end{abstract}

Keywords: Religious minorities; institutional relation model; freedom of religion; Portugal

Resumo: Ao longo do último quartel do século XX, o nascente regime democrático português procurou não hostilizar a hierarquia católica. Ciente dos problemas de algum forte agastamento, as forças políticas de esquerda que ganharam o poder depois de 1974 pouco afrontaram a Igreja Católica retirando-lhe direitos.Longe de se retirarem direitos adquiridos, deu-se lugar a uma mecânica em que às minorias foi dada possibilidade de ascender ao mesmo patamar de relação que o Estado tinha com a religião dominante. Por exemplo, através do tempo de antena nas rádios e nas televisões públicas e no espaço confessional das escolas. Valorizadas e respeitadas, as minorias aderiram a estes modelos, defendendo-o como a mais perfeita concretização - sintomática é a redação da Lei de Liberdade Religiosa de 2001. Hoje, temos as minorias a apoiarem o status quo, defendendo o lugar e a posição da Igreja católica, por medo de perderem os seus direitos para, na prática, nada retirar à maioria.

Palavras-chave: Minorias Religiosas; Modelo de relação institucional; Liberdade Religiosa; Portugal

\footnotetext{
${ }^{1}$ Coordenador da Área de Ciência das Religiões da Universidade Lusófona de Lisboa. pmpgeral@gmail.com
} 


\section{New State's deep impression}

During the Democratic Revolution in 1974, Portugal survived a long political history and an even stronger impression in mentalities. In fact, the New State claimed the catholicity of the Nation, in a breaking point with the previous regime that would establish religious freedom in 1910, developing even a certain persecution of Catholic clergy.

The Constitution of 1933 maintained the separation of state from religion, affirming the freedom of belief and religious practice, but affirmed the Catholic religious identity of their own "nation." As a corollary, in 1940 it was signed a Concordat with the Vatican, and the Catholic authorities and entities remain one of the more solid marks of the political regime that lasted until 1974, with a small adaptation in the constitutional revision of 1971, where it says:

Art. 45 Free is the cult of Catholic religion, private or public, as a religion of the Portuguese nation. [...].

Yet....

Art. $46 .^{\circ}$ The Roman Catholic religion is considered as the traditional religion of the Portuguese nation.

Only the Law 4/71, a few days after the date of approval of this constitutional amendment, significantly clarifies the religious issue, fully ensuring some liberties, but always taking Catholicism as the religion, by default:

\section{Fundamental I}

The State recognizes and guarantees the religious freedom of the people and ensure adequate legal protection to the religious denominations.

Fundamental II

1. The State does not profess any religion and its relations with religious faiths are based on a regime of separation.

2. Religious denominations are entitled to equal treatment, except for differences imposed by their different representativity. 


\section{The new framework with the Democratic Revolution}

The post-revolution constitution has simplified the relations between the State and religious denominations. In its 'Part I: Fundamental rights and duties "," Title I: General principles', Article 13 (Principle of equality), point 2, the question is clearly put:

No one shall be privileged, favored, prejudiced, deprived of any right or exempted from any duty because of ancestry, sex, race, language, place of origin, religion, political or ideological beliefs, education, economic situation or social condition.

In Article 41 (Freedom of conscience, religion and worship), the law begans to cover and include all religions, without leaving any trace of the one that had been seen as traditional religion.

Now, returning to the relation between religious denominations and teaching, in Article 43, the issue of education is taken:

2. The State shall not assign the right to plan education and culture according to any philosophical, aesthetic, political, ideological or religious guidelines.

3. Public education shall not be denominational.

The Portuguese Constitution of 1976 has opened a new cycle in respect of this issue, but more than a dozen years, the situation was quite similar. Only in 1987, more than a dozen years after the 1974 revolution, the time arrives for the Constitutional Court take its the first step by declaring unconstitutional Articles 1, 3, 4, 5 and 6 of Decree-Law No. 323/83, of 5 July, which had consecrated that the state would minister the Catholic teaching of religion and morality in public schools.

\section{The imitation of a model: religion and exclusion}

The relation between the Portuguese State and the religious universe was almost never easy. Since very ancient times, these relations are governed by the oscillation between frank approach moments, that became merged, or overlapping by moments of clear confrontation. 
Recent history has maintained this emphasis, this feature capable of creating a deeper line of ambiguity. Far from defining clear rules, relations between the state and the religious universe often sought vagueness, often escape the law, the balance - or should we say wise balance- between customary and legislated.

For example, after April 25th, there was a movement of legislation production that consecrated freedoms and guarantees. However, in this context, the need to develop a "Religious Freedom Law." it was not quikly felt. Only about 30 years later, the law would be redacted and approved. Looking at this disconcerting fact, we are led to some reflections. In fact, maybe it was not necessary: the Constitution already guarantee this freedom. And the same can be said for the other "Laws of Freedom ..." which, in addition to the constitutional articulated, received other specific and regulatory instruments.

Indeed, freedom of worship, practice or religious choice never been at stake in a democratic Portugal. Asfor the individuals, their freedoms and guarantees naver have been curtailed. As for the organizations level, the question was radically different; It is to where the focus must be applied.

Religious diversity in Portugal was (and still is) very small according to statistics, and religious groups more willing to the commitment of civic intervention, did intervene (and still do) essentially at the level of social work, accepting naturally a place of growing proximity to the model of relations that the state had with the dominant confession.

But not only on the level of social work it has been created an approach to a practice maintained from the model of the Catholic universe. The case of the television service was at all similar. Not putting into question the airtime for the Catholic Church, it created a situation in which the other confessions made possible to build the same "service" having a religious program in the state channel - Catholicism ended up gaining the most significant part of emissions between confessions, of course, for historical reason and social representation. The school is the ultimate place of this imitation model. Almost all the legal work done, was not focused in the withdrawal of the Catholic teaching discipline, but in the inclusion of other religions in this space by laws of "rising" inclusion. 
The increasing openness of state institutions to the universe of religions happened in direct imitation of the rights that were traditionally assigned to the Catholic Church: space on public television and school space in secondary education.

The controversy surrounding the State Protocol was, once again, the simple result of the state's ambiguity in these matters.

Following the tradition, of the Catholic Church, in certain ceremonies the dignity of presence of this confession was maintained. Now that it has been discussed a State Protocol Act, it was raised the idea of, not the removal of figures of the Catholic Church's official list, but the creation of places for other confessions. The model returns to exactly the same: the imitation of earlier existing model.

Democratically, this situation is deplorable. This mechanical approach of some confessions to the rights traditionally attributed to the Catholic world has created as a process of "gentrification" without pre-established criteria.

This whole process has several detrimental effects. On one hand, they created a leverage where one can claim to what Catholics are, and others do not. Consequently, it created a very strong curtain almost impossible to remove, since in practice this ascension scheme turned all parties in obvious defenders of the status quo.

Basically, small denominations that are legitimized by this form of action and choice, accept this mechanics, to the extent that this recognition by a state institution is seen as the rise of opportunity to a degree of accreditation, dignification.

Finally, in addition to this phenomenon of "gentrification", this tacit recognition by the state, it creates an almost impossible situation to change, because in the bringing together of various confessions, the peripheries are born, and consolidate themselves, so those who do not enter the criteria of laws of teaching, television, etc., etc., etc . are cast aside, or in a word, the newly excluded are born.

Now that we came to this, it is of most interest questioning the place of confessions that are purposely left out. They are not terrorist groups or dangerous ones. They are 
confessions that in some cases, little is make known, but that aggregate around them hundreds of thousands of faithful who, let us not forget, are national citizens of ours.

Whatever the judgment we make about some religions, the definition of standards of relations between the state and a still significant portion of its citizens should not be based on any prejudice vision or worse, a pure inattention or legislation neglect. Whatever the belief of individuals, it does not make them, or convert them into citizens less relevant by the state.

\section{References}

ALMEIDA, Dimas; CRUZ, Braga da; PORTAS, Miguel; KESHAV- JEE, Faranaz; MACHADO, Jonatas. Estado e liberdades religiosas. Mesa Redonda. In: Revista Portuguesa de Ciência das Religiões. n. ${ }^{\circ}$ 1, 2002, Lisboa, pp 135-158.

ALMEIDA, Luís Nunes de; BRITO, Sousa e; BRAVO, Dias; MIRANDA, Jorge; MOREIRA, Vital. 'Lei da liberdade religiosa e revisão da Concordata'. In: Fórum Iustitiae. 16, Nov de 2000, pp. 5-20.

BAUDÉROT, Jean, dir. Religions et laicité dans l'Éurope des douze. Paris, Syrios, 1994.

BRAVO, Dias. "Educação e liberdade religiosa". Revista Portuguesa de Ciência das Religiões, n. ${ }^{\circ}$, 2002, Lisboa, pp. 51-58.

DEBRAY, Règis. L'enseignement du fait religieux dans l'école laique: rapport au Ministre de l'Éducation Nationale. Pref. Jack Lang, Paris, Odile Jacob, 2002.

MACHADO, Jónatas. A liberdade religiosa na perspectiva das liberdades fundamentais'. In: Revista Portuguesa de Ciência das Religiões, n. ${ }^{\circ}$ 1, 2002, Lisboa, pp 149-154.

MACHADO, Jónatas. O Regime Concordatário entre a «Libertas Ecclesiae» e a Liberdade Religiosa. Coimbra, Coimbra Editora, 1993.

MEIRIEU, Philippe. Relatório Meirieu para a reforma do ensino médio em França. Brasília, Instituto Nacional de Estudos e Pesquisas Educacionais, 1999.

VALENTE, David; FRANCO, Alberto. Liberdade Religiosa. Nova Lei: anotada e comentada. Lisboa, Dislivro, 2002. 